\title{
A Laicidade no Debate Filosófico-Político Atual
}

\author{
André Gonçalves Fernandes*
}

\begin{abstract}
RESUMO: num ambiente político liberal em que se fomenta vivamente um construtivismo politico (Rawls), as igrejas podem participar na esfera pública, porque a cultura religiosa pode iluminar certos aspectos vitais que, num contexto epistemologicamente cientificista, racionalmente instrumental e financeiramente economicista, restaram esquecidos, na medida em que as religiões não cessam de plasmar os modelos culturais das grandes civilizações (Habermas).
\end{abstract}

Palavras-CHAVE: Estado de Direito; Religião; Rawls; Habermas; Ratzinger.

\section{Introdução}

O presente ensaio pretende investigar, analisar e considerar as raízes filosóficas do debate político atual acerca da laicidade. Não se cuida tanto de recorrer aos cânones do contratualismo ilustrado, mas aos fundamentos possíveis do contratualismo vivido nas sociedades ocidentais e, por isso, é necessário tratar com especial atenção três pensadores que têm aparecido reiteradamente nas referências dos estudiosos das relações entre Estado de Direito e Religião: trata-se de Rawls, Habermas e Ratzinger.

Habermas conseguiu debater com os outros dois pensadores. O primeiro debate, em torno do liberalismo político e suas possibilidades na aplicação das atuais democracias plurais, ocorreu com Rawls e será objeto de estudo da primeira parte deste ensaio. Com Ratzinger, no segundo debate, Habermas argumenta em prol de uma ardente dialética da secularização, onde, partindo do debate anterior com Rawls, enfoca o problema da religião como o fundamento moral ou normativo das atuais democracias.

Nas linhas seguintes, delinearemos os perfis de cada um desses diálogos para, a partir deles, procurar esclarecer os horizontes do conhecimento no

\footnotetext{
*CEU Law School/UNICAMP/UNAV
} 
tema da laicidade, fazer emergir as tensões entre as esferas política e religiosa, suscitar limites de atuação de uma e outra e, ao cabo, desvelar os vínculos cooperativos entre tais órbitas existenciais, em prol da busca, no assunto da laicidade, da totalidade do real em suas conexões globais e muito além dos herméticos muros epistemológicos de um laicismo que, ao se dizer esclarecido, na práxis política, é completamente obscurantista.

\section{Habermas: genealogia de um problema}

A configuração da atual situação moral, social e política tem seu início no pensamento iluminista, que vai tomando corpo até se transformar numa tentativa de abordar sistematicamente o quadro problemático em que se situa o debate de que trataremos aqui, relativo à laicidade nas relações entre Estado de Direito e Religião.

Num louvável intento de abordar sistematicamente a complicada trama do problema da laicidade, Habermas dirige nosso olhar para a forma como as estruturas de desenvolvimento sociopolítico estão sendo descobertas, isto é, os Estados-nação. A relação entre a nação, o estado de direito e a democracia pode ser o eixo inicial a partir do qual podemos ver como os outros problemas colaterais se entrelaçam ao debate fundamental que aqui nos preocupa, mormente o do liberalismo político. ${ }^{1}$

De acordo com Habermas, "o Estado nacional e a democracia emergiram da Revolução Francesa como gêmeos. E, culturalmente, estão à sombra do nacionalismo", o que o leva a considerar este fenômeno como algo especificamente moderno e cuja direção é orientada para a integração cultural. A explicação do conceito de nação remete-nos, desde a Antiguidade, à integração geográfica, linguística, étnica e cultural das comunidades de origem, ainda não reguladas politicamente por um organismo estatal. ${ }^{2}$

A consciência nacional modema nasce, no entanto, como estratégia libertadora frente aos poderes da sociedade de classes, estando ligada a alguns processos de modernização socioeconômica que supõem uma nova for-

\footnotetext{
${ }^{1}$ Essa relação merece ser estudada detidamente no terceiro capítulo da obra La inclusión del otro, de Jurgen Habermas (Barcelona: Paidós, 1999), pp.107-135.

2 Jurgen Habermas, Facticidad y validez (Madrid: Trotta, 1998), p.622.
} 
ma de integração e que experimentarão um processo de dinamização a partir do advento da autonomia individual pelo liberalismo do século XIX.

Segundo Habermas, "a nação é uma forma de consciência que pressupõe uma apropriação das tradições culturais filtradas pela historiografia e pela reflexão" e que "surge no público burguês culto"3. Mas, à medida que a Modernidade avança, outro sentido é incorporado, pois, em meados do século XVIII, nação significa tanto uma "comunidade de descendência" como a população de um Estado, a apontar para o "direito à autodeterminação política, a fonte da soberania do ente estatal" "5.

Segundo a concepção clássica do final do século XVIII, o povo de um Estado que se constitui como tal e se dá uma constituição democrática é denominado de nação ${ }^{6}$. Portanto, com a Revolução Francesa, o que era entendido como uma situação pré-política passou a ser a "identidade política dos cidadãos de uma comunidade democrática"7.

O conceito de cidadania desenvolve-se a partir do conceito rousseauniano de autodeterminação. Inicialmente a expressão "soberania popular" tinha sido entendida como uma restrição ou inversão da soberania do príncipe, soberania que repousava num contrato entre o povo e o governo.

Em contraste, Rousseau e Kant não entendem a soberania popular como uma transferência de poder político de cima para baixo ou como uma distribuição de poder político em duas partes. Para eles, a soberania popular significa a "transformação da dominação política em auto legislação"8.

\footnotetext{
3 Idem. trutivismo de John Rawls.

${ }^{5}$ Habermas, Facticidady V alider, p. 622.

${ }^{6}$ Habermas, Inclusion del otro, p. 112.

${ }^{7}$ Habermas, Facticidad y Valider, p. 622.

${ }^{8}$ Ibid., p. 623.
}

${ }^{4}$ Essa ideia de comunidade de descendência parece ter impacto nos critérios científicos que Rawls exige de si mesmo, ao tomar, como campo de trabalho, uma geração completa, desde o nascimento sob um determinado Estado, até a morte e legado aos seus descendentes do paradigma político em questão. Vemos aqui - como iremos desenvolver ao longo dessas linhas - uma referência ao etnonacionalismo, delineado a partir da perspectiva do nascimento sob umas condições sociais, políticas e culturais, no cons- 
Desse modo, o cidadão é um sujeito autônomo, capaz de se autogovernar de acordo com as leis que se decidem no aparelho estatal que agora não lhe é alheio, mas que está diretamente relacionado a ele, a partir do contrato pelo qual se estabelecem as relações sociais, políticas e legais.

Como ressalta Habermas, "a progressiva inclusão da população na condição de cidadão abre para o Estado não apenas uma nova fonte secular de legitimação, mas também gera um novo patamar de integração social mediado por lei" ". Este é, inicialmente, um esboço do modelo ilustrado. Mas ainda podemos expor uma variante evolutiva que continua até hoje com grande força e relevância.

Trata-se da concepção romântica de povo, que passa a afirmar sua existência e diferença na luta com outras nações na assunção espontânea de uma origem e linguagem comuns e enraizada na ficção de um passado comum transformado em comunidade de destino. Este modelo, agora ressurgente - os novos nacionalismos da Europa do Leste, as autoafirmações locais e a imigração africana são um bom exemplo disso - dá origem ao que Habermas chamou de terminologia não inocente: etnonacionalismo.

Este conceito de origem romântica, mas pleno de atualidade, colocará de manifesto a concorrência nuclear de duas categorias: etnia e nação, que têm em comum uma arraigada consciência do "nós", entendido como demos (povo). Habermas acentua que "este conceito etnológico de nação entra em competição com o conceito utilizado pelos historiadores, porque apaga qualquer referência específica ao ordenamento jurídico positivo do estado democrático de direito".

O reflexo deste nacionalismo, moldado a partir da estreita ligação entre ethos e demos, tem, em sua origem, um modelo de liberdade coletivo baseado na autoafirmação nacional perante os outros - reafirmação da consciência do nós, a que aludimos anteriormente - apta a transferir para a liberdade do "nós" um caráter ambivalente, na medida em que supõe uma abertura interior assentada numa oclusão para o exterior.

O pressuposto estabelecido é o de que o demos deve estar enraizado no ethos para se alcançar uma comunidade jurídica formada por cidadãos livres e iguais; uma verdadeira falácia, pois "conceitualmente, a cida-

${ }^{9}$ Habermas, Inclusión del otro, p. 111. 
dania sempre foi independente da identidade nacional e esta liberdade nacional não coincide com a genuína liberdade política dos cidadãos no fundo da questão"10.

O efeito disso será sentido na posterior compreensão de liberdade republicana, a qual restará desvinculada da liberdade nacional, embora possamos localizar sua origem nela. Habermas acentua que "sociedades multiculturais, como a Suíça e os Estados Unidos, mostram que, numa cultura política, para que os princípios constitucionais nela se enraízem, não é necessário o apoio numa origem ou origem étnica, linguística e cultural comum a todos os cidadãos"11.

Habermas ainda afirma, reiteradamente, que o nacionalismo não é um requisito necessário para um processo democrático, pois a identidade da cidadania não coincide com os traços étnico-culturais, mas com "a práxis dos cidadãos que exercem ativamente os seus direitos democráticos de participação e comunicação"12.

Como exemplo bem concreto disso, Habermas traz à colação a construção e o perfil etno-nacionalista da Constituição de Weimar (Schmitt), na qual se estabelece uma nítida separação entre a ordem jurídica e a ordem política, partindo a nação como uma dobradiça formada, de um lado, pelos princípios herdados do estado de direito burguês e, de outro, pelo princípio democrático da autodeterminação popular, do qual se infere a necessidade de uma homogeneidade nacional para o exercício democrático do poder político.

Em outras palavras, para este perfil, a democracia só pode ser exercida como uma práxis comum, cuja igualdade interna é identificada e requer uma igualdade substancial, na qual o conceito fundamental é o de povo em oposição ao de humanidade. Em suma, a nação faz a mediação entre o estado de direito e a democracia, porque participam do poder democrático apenas as pessoas, entendidas como indivíduos da esfera privada, convertidas em nação política.

\footnotetext{
${ }^{10}$ Habermas, Facticidad y Valider, p. 110.

${ }^{11}$ Ibid., p. 628.

12 Habermas, Facticidady Valider, p. 622 e Inclusión del otro, p. 111.
} 
O efeito prático disso será o da “dissociação entre o marco legal regulatório do tratamento privado na sociedade civil e o republicanismo inspirado no direito racional"13. Neste discurso, Habermas oferece-nos uma apreciação quase simultânea de modelos contemporâneos sobre os quais devemos trabalhar e que podem ser agrupados em duas tradições: a liberal (Locke na esfera anglo-saxônica) e a republicana (Aristóteles e Kant na esfera romano-germânica).

Estas tradições competem, entre si, em sua filosofia do Direito, no que diz respeito à interpretação de uma verdadeira cidadania ativa. Tomando, como referência, as sociedades contemporâneas, então, vemos como elas são coesas segundo dois fatores fundamentais: o mercado e a administração pública, delimitando-se, umas e outras, "segundo uma consciência nacional implicadora de uma inclusão ampliada simultaneamente com uma exclusão renovada"14.

A solução para este quadro polifacetado, de acordo com Habermas, estaria em duas localizações possíveis, a saber, o plano da cultura e o plano dos procedimentos democráticos: "nas sociedades pluralistas, esse fardo não pode ser deslocado do plano da formação da vontade política e da comunicação pública para o do substrato cultural aparentemente natural de um povo homogêneo"15.

Portanto, toda a estruturação do aparato político e jurídico residirá na exigência de um procedimento de promulgação de leis, onde se deposita uma soberania procedimentalista em face de um futuro que não demande render contas históricas a respeito de presunções étnicas ou culturais. A legitimidade do Direito democrático advém, então, do mesmo procedimentalismo democrático, que não requer qualquer consenso pré-político, porque a práxis cidadã possibilita um acordo entre estranhos, de sorte que o procedimentalismo sub-roga-se nas carências de integração social, assegurando o valor de uso das liberdades subjetivas.

Com efeito, se nos limitarmos a tentar estabelecer soluções a partir do plano cultural, pode acontecer - e temos exemplos contemporâ-

\footnotetext{
13 Habermas, Inclusión del otro, p. 113.

14 Ibid., p. 109.

15 Ibid., p. 116.
} 
neos que reforçam isso ${ }^{16}$ - que o efeito resulte contraproducente. Por outro lado, se um artifício cultural é imposto no seio comunitário, a inaceitabilidade social inevitavelmente provocará um conflito. Se supusermos, pelo contrário, que uma cultura empoderada atenda a certas tradições de um grupo supostamente homogêneo, cairemos no mesmo erro que vimos antes, isto é, no império do etnonacionalismo, com todas suas características conhecidamente excludentes.

Daí que a cultura, assim entendida, não possa ser, neste momento, a solução para os problemas supervenientes. A compreensão do procedimentalismo requer um certo grau de atenção, porque estabelece o nexo entre Estado de Direito e a democracia ${ }^{17}$ que o republicanismo favorece, pois "este nexo conceitual rege também aquela dialética entre a igualdade jurídica e fática que, em face da compreensão jurídico-liberal, primeiro, ofereceu o paradigma jurídico do Estado do Bem-Estar Social e, hoje, demanda por uma autocompreensão procedimentalista do Estado democrático de Direito"18.

Por que o procedimentalismo é tão importante no cenário político contemporâneo? Entendemos que o dado político não pode ser separado da compreensão geral do mundo em que se desenvolve. O pensamento contemporâneo, então, é marcado por um critério procedimental, cujas linhas são as seguintes:

a. As ciências experimentais modernas e uma moralidade que se emanciparam e tornaram-se autorreferentes, agora, contam apenas com aquilo que lhes sobrou, isto é, a racionalidade de seu próprio pro-

\footnotetext{
16 Referimo-nos, por exemplo, ao problema argelino em que a crise de identidade, produzida após a colonização francesa, faz com que o aparelho de Estado implante uma cultura popularmente tão alheia e estranha à população, como se deu com os colonizadores europeus. Isso supõe uma desintegração social causada pela inadequação de critérios culturais radicalmente artificiais e que, ao cabo, criam feridas abertas cuja cicatrização, a curto ou médio prazos, é praticamente impossível.

17 A exemplo da constituição de Weimar, a nação era uma dobradiça, ou seja, cumpria a função de nexo entre Estado de direito e democracia. Esta funcionalidade restringia os princípios democráticos à circunscrição do dado nacional, conferindo ao Estado de Direito uma exclusividade territorial inapropriada. Agora, com a política procedimentalista, estabelece-se a salvaguarda que torna a política um objeto impersonalizado de autonomia funcional, a assegurar, na medida de sua funcionalidade, a imparcialidade das instituições e da justiça devida aos cidadãos.
}

18 Jurgen Habermas, La filosofia moral y politica (Madrid: Biblioteca Nueva, 1997), p. 24. 
gresso e de seu procedimento, a saber, respectivamente, os métodos do conhecimento científico e do conhecimento teórico.

b. A racionalidade fica encolhida e se reduz a mera formalidade a se evaporar assim que dá validade aos resultados alcançados.

c. A racionalidade per se depende, agora, da racionalidade dos procedimentos, os quais foram desenhados para resolver os problemas empíricos e teóricos - nas comunidades de pesquisa e no âmbito da ciência organizada e os problemas prático-morais na sociedade de um Estado democrático e no sistema legal.

d. Como o dado racional não pode valer segundo a ordem de coisas em que o sujeito se encontra no mundo ou que nasce do próprio processo de formação do espírito, então, "a solução dos problemas que alcançamos em nossas relações com a realidade só podem passar pela validade epistemológica dos procedimentos"19.

e. Ao cabo, a racionalidade procedimental não pode mais garantir uma unidade prévia na diversidade dos fenômenos.

Convém, agora, analisar as características gerais dos modelos democráticos liberal e republicano, tais como são entendidos por Habermas em suas obras paradigmáticas, e, ao mesmo tempo, relacioná-los aos conceitos de cidadania e de direito, sempre segundo a natureza do processo de formação da vontade política democrática.

De acordo com Habermas, a tradição liberal tenta programar o Estado de acordo com os interesses da sociedade, mas, em sua própria conceituação, ele separa a categoria estatal, a servir ao aparelho da administração pública, da categoria social, que "serve ao sistema de inter-relação dos indivíduos na esfera privada e ao trabalho estruturado em termos de economia de mercado" 20 .

O processo político liberal supõe uma luta pela conquista de posições que busquem a disposição do aparato administrativo, o que se traduz na conquista de esferas de poder. O sucesso desse processo é medido ${ }^{21}$ quanti-

\footnotetext{
${ }^{19}$ Jurgen Habermas, Pensamento post-metafísico (Madrid: Taurus, 2000), p. 45.

${ }^{20}$ Habermas, Inclusión del otro, p. 231.

21 Ibid., p. 236.
} 
tativamente pelo desempenho em processos eleitorais onde as preferências dos cidadãos supõem-se estar refletidas. As regras irão garantir a equidade do processo eleitoral e "o processo de formação da vontade democrática tem exclusivamente a função de legitimar o exercício do poder político"22.

No que toca ao ordenamento jurídico, a concepção liberal proporcionará um mecanismo que "permita determinar, em cada caso, quais direitos correspondem a quais indivíduos"23. Portanto, pode-se afirmar que o liberalismo constrói seu ordenamento jurídico a partir de direitos subjetivos.

Por fim, a tradição liberal entende a cidadania segundo o modelo de pertença a uma organização de base legal, onde os cidadãos permanecem alheios ao Estado e sua contribuição é exercida pelo voto e pelo pagamento de tributos, "essencialmente não se distinguindo dos indivíduos que afirmam seus interesses frente ao aparato estatal" 24.

Conforme Habermas,

o objetivo da argumentação liberal é dirigido contra o potencial perturbador de um poder estatal que impede a interrelação social autônoma dos indivíduos. O ponto crucial do modelo liberal não é a autodeterminação democrática dos cidadãos que deliberam, mas a padronização, em termos do Estado de Direito, de uma sociedade voltada para a economia que, ao satisfazer as expectativas de felicidade privada dos cidadãos ativos, deve garantir um bem-estar geral entendido de forma apolítica ${ }^{25}$.

Conforme Habermas, a tradição republicana é aquela em que ele percebe uma maior proximidade de seu projeto. O republicanismo goza de uma compreensão intersubjetivista da soberania popular que implica, por parte dos cidadãos, a assunção de compromissos e aceitabilidade racional, atributos que se afinam em muito com os postulados do projeto político.

22 Ibid., p. 243.

${ }^{23}$ Ibid., p. 235.

${ }^{24}$ Ibid., p. 232.

${ }^{25}$ Ibid., p. 241. 
Evidente que essa leitura do republicanismo é feita por Habermas ${ }^{26}$ a partir de sua teoria da ação comunicativa, considerando ser a mais adequada e apta a permitir compreender a política a partir de um conceito não-instrumental baseado numa concepção de pessoa que atua comunicativamente.

Segundo a concepção republicana, a política não se esgota numa função mediadora, mas se estabelece como fator constitutivo do processo de socialização, "uma forma de reflexão numa estrutura de vida ética"27. Aqui, o espaço político público e a sociedade - como infraestrutura garantem, em conjunto, sua força integradora e sua autonomia à prática da inter-relação dos cidadãos.

$\mathrm{Na}$ concepção republicana, os direitos subjetivos baseiam-se num ordenamento jurídico objetivo, que afiança e possibilita a integridade de uma vida comum autônoma no marco regulatório da igualdade de direi$\operatorname{tos}^{28}$, pelo fato dessa concepção conferir igual dignidade à integridade dos indivíduos do que à integridade da comunidade.

O sistema de mercado e seus processos ficam de fora da opinião e da vontade política, que apenas atende às estruturas próprias de comunicação pública voltadas para o entendimento mútuo, cujo paradigma de autodeterminação cidadã jaz na relação intercomunicativa, isto é, no diálogo. Portanto, a construção republicana de um Estado de Direito democrático sempre implicará uma autocompreensão ética da prática deliberativa apoiada num consenso cultural ${ }^{29}$.

Nesse mesmo ponto, Habermas coloca adiante a vantagem da compreensão republicana, em comparação com a desvantagem do idealismo, que faz a democracia depender das virtudes de seus cidadãos. A tradição republicana supõe que o cidadão está vinculado a uma comunidade ético -cultural autodeterminada. Ele se integra à comunidade como parte de um todo, alcançando sua identidade privada e social no horizonte de reconhecidas tradições e instituições comuns e atualizando sua carta de cidadania mediante a prática da autodeterminação coletiva ${ }^{30}$.

\footnotetext{
${ }^{26}$ Ibid, p. 118.

27 Ibid., p. 231.

28 Ibid., p. 235.

${ }^{29}$ Ibid., p. 234.

30 Ibid., p. 232.
} 
Na ótica de Habermas,

vejo o quid do republicanismo no fato de que as formas e procedimentos do Estado constitucional, juntamente com o modo democrático de legitimação, produzem um novo nível de coesão social. A cidadania democrática - no sentido de citizenship - estabelece uma solidariedade comparativamente abstrata entre estranhos e, em qualquer caso, mediada legalmente. E esse modo de integração social realiza-se por meio da forma própria de um contexto comunicativo que intervém, inclusive, na socialização política ${ }^{31}$.

\section{A proposta de Rawls: o liberalismo político}

A iniciativa política de Rawls, ao contrário daquela apresentada por Habermas, parte de um interesse estritamente pragmático, típico da mentalidade anglo-saxônica, diante da situação em que se situam os quadros social, político e jurídico no mundo ocidental contemporâneo, caracterizados pela concomitante pluralidade de critérios, raças e afinidades díspares destinados a coexistir no âmbito de uma sociedade democrática.

Essa observação levanta uma questão decisiva para Rawls: como é possível "a existência duradoura de uma sociedade justa e estável de cidadãos livres e iguais, que ainda estão profundamente divididos por doutrinas religiosas, filosóficas e morais dotadas de razoabilidade"?32

Rawls adverte que "não há, no momento, nenhum acordo geral sobre como as instituições básicas de uma democracia constitucional devem satisfazer em termos equitativos de cooperação entre cidadãos considerados livres e iguais" 33 . Isso obriga, portanto, a uma reflexão sobre as próprias instituições, além de considerar os propósitos que as justificam socialmente.

A exigência de que o marco inicial seja uma democracia constitucional já nos alerta que estamos situados numa perspectiva específica e própria de um determinado modo de vida: um locus em que os cidadãos partem de uma situação originária de liberdade e igualdade. A ideia de Rawls

\footnotetext{
31 Ibid., p. 141.

32 John Rawls, El liberalismo político (Barcelona: Herder, 1996), p. 33.

33 Ibid., p. 34.
} 
consistirá, fundamentalmente, em debruçar-se na construção de uma concepção política de justiça: a justiça como equidade.

Nessa tarefa, devem ser descartados todos os preconceitos particularistas, incluindo (ou, melhor dizendo, principalmente) aqueles que dizem respeito às várias confissões religiosas, a fim de atingir o propósito levantado pela pergunta inicial. Partindo, então, da necessidade de reconstrução da estrutura social básica, que entende ser constituída por um regime democrático, ele considera que esta estrutura deve ser constituída pelas principais instituições sociais, políticas e econômicas, que se complementam "num sistema unificado de cooperação social de geração em geração"34.

Rawls constata que a cidadania de uma sociedade democrática está imersa numa cultura pública que não concebe a ordem social como um dado fixo e que não é mais natural, religioso ou aristocrático, mas dinâmico, laico e mutável, passível de ser transformado, dependendo das conveniências sociais, políticas ou econômicas que, por um lado ${ }^{35}$, melhorem as possibilidades de coexistência num ambiente de liberdade e de igualdade e que, por outro, sejam consistentes com os critérios de razoabilidade vigentes nos princípios emanados dessa cultura pública ao qual aludimos antes.

Essa estrutura básica, voltada para a cooperação social entre gerações, implica na responsabilidade histórica de se deixar um legado prático que possibilite a mútua convivência, não apenas num determinado espaço, mas também na durabilidade do tempo. Supõe, portanto, um esforço para deixar assentadas as bases de uma sociedade bem ordenada, onde o exercício da liberdade e da igualdade exigidas pelos cidadãos de uma sociedade democrática seja possível.

Isso significa que esse tipo de sociedade - sociedade democrática bem ordenada, como a denomina Rawls - deve ser estritamente configu-

\footnotetext{
${ }^{34}$ Ibid., p. 41. A questão geracional é muito importante no propósito de Rawls. Em princípio, parece que podemos verificar que tomar uma geração - que por outro lado corresponde a um ciclo de vida completo - tem a conotação de tomar uma amostra estatística. Posteriormente, comentaremos sobre outras conotações diferentes extraíveis desse fato. Em todo caso, basta reconhecer que isso define em recorte epistemológico em seu campo de estudo.
}

35 Ibid., p. 45. 
rada no "domínio do político"36. Dito de outra maneira, a ideia é a de tentar constituir uma estrutura básica viável para a coexistência pacífica e duradoura de cidadãos livres e iguais, onde supomos que cada um contemple critérios morais, filosóficos ou religiosos diversos

Em princípio, esses critérios, dito de razão não pública, não têm lugar na construção da estrutura comunitária, porque ultrapassariam os propósitos estritamente políticos que Rawls pensa em sua proposta de filosofia política. Com efeito, o que nos interessa aqui é - fundamentalmente - a construção das bases comunitárias, de sorte que o Estado, para garantir a coesão social, deve exercer coerção com respeito, sobretudo, às doutrinas onicompreensivas, por mais razoáveis que sejam ${ }^{37}$.

A estabilidade social leva-nos a contrair certas implicações enormemente interessantes e decisivas na ordem construtiva de uma política e uma justiça procedimentalistas, o que, além disso, justifica e afeta a questão geracional que já mencionamos acima. Por um lado, Rawls argumenta que nascer e crescer sob instituições justas desenvolverá, nos cidadãos, um tal senso de justiça que criará neles uma tendência a obedecer a essas instituições.

Por outro lado, os hábitos de crescimento nesta esfera fomentarão um clima apropriado para o surgimento de uma cultura política pública dotada de razoabilidade, suscetível de se tornar o foco de um consenso sobreposto (overlapping consensus) ${ }^{38}$. Embora a justificativa de Rawls seja entendida num plano da configuração cultural não ofensiva da idiossincrasia particular de cada cidadão ou grupo de cidadãos, a expressão por ele manejada - a obediência - não nos parece a mais adequada, pois não se trata de submeter-se às instituições, segundo hábitos vitais, mas antes que estas assegurem a autonomia pessoal no domínio da igualdade e da liberdade próprias de uma sociedade democrática.

\footnotetext{
36 Ibid., p. 69.

${ }^{37}$ Rawls traz os textos de Kant ou Mill a respeito dessa afirmação da opressão do Estado, mas podemos exemplificar com um fato contemporâneo: o Estado francês proíbe estritamente qualquer indumentária que manifeste uma adesão religiosa específica que, de alguma forma, seja excluída dos princípios laicistas que dominam a cultura social. A famosa polêmica sobre o véu que as muçulmanas são obrigadas a usar, segundo seus preceitos religiosos - errados ou não - vem sempre à tona quando o governo francês pró́be seu uso em instituições públicas como escolas. 38 Ibid., p. 173.
} 
Pretende-se, portanto, estabelecer as bases de um regime constitucional com estas características essenciais, mas, sobretudo, por uma relação entre as pessoas no quadro da estrutura básica da sociedade, uma estrutura de instituições básicas em que somos incorporados pelo nascimento e só saímos quando morremos.

Tudo "acontece como se simplesmente nos materializássemos, por assim dizer, e suspendêssemos ex nibilo nossa posição atual do mundo social, com todas as suas vantagens e desvantagens, de acordo com nossa boa ou má sorte. Dizemos do nada, porque carecemos de uma identidade anterior pública ou não pública prévia"39, porque não viemos para este mundo social de outro lugar. A sociedade política "é fechada e só nela podemos ser, somado ao fato de que não entramos ou saímos voluntariamente e nem podemos fazê-lo" 40 .

Portanto, o que buscamos, em Rawls, é um princípio de legitimidade do poder político no quadro dos princípios liberais e isso implicará a recorrência à construção de um marco constitucional pautado numa racionalidade procedimental, "como fiadora da justiça básica ou das questões colaterais mais próximas" 41 .

Todavia, deve ficar muito claro que esse construtivismo político é oposto ao construtivismo moral, porque não se trata de definir as características de uma rąão prática, ou seja, não se trata de elucidar ou criar uma moral ou ética específica, mas sim de "definir o marco inaugural em que esses princípios são aplicáveis" 42 .

A proposta política que Rawls nos oferece não é outra senão o liberalismo político, entendido como uma práxis capaz de conceber "aquela diversidade de doutrinas razoáveis como o resultado inevitável, a longo prazo, das faculdades da razão humana desenvolvidas no quadro das instituições livres" 43 .

\footnotetext{
39 Ibid., p. 167.

41 Ibid., p. 169.

42 Ibid., p. 16.

43 Ibid., p. 33.
}

${ }^{40}$ Idem. Nota-se que Rawls resolve aqui um dos problemas tradicionais dos teóricos contratualistas, especialmente Rousseau, pois sempre falam de como o homem entra na situação de contrato social a partir de um estado de natureza ideal e presumido e nunca se resolve ser ou não possível abandonar esse contrato. 
Doutrinas razoáveis, entre as quais deveriam incluir-se as de origem religiosa. O construtivismo político de Rawls teria seus limites no procedimento de uma ordem representativa de valores políticos, cujo ponto de partida são os princípios expressos pelos valores da razão prática. A isso o liberalismo político acrescenta ser a ordem mais apropriada para uma sociedade democrática imersa em um pluralismo razoável, e na medida em que fornece a concepção mais razoável de justiça e se converte no foco de um consenso sobreposto.

O que é o construtivismo político, que visa formular e estabelecer uma concepção de justiça política? Segundo Rawls, tem quatro características fundamentais:

a. Atende à representação da justiça política como o resultado procedimental do construtivismo;

b. Baseia o procedimento construtivista na razão prática e não na teorética, ou seja, requer uma razão de funcionalidade que dispensa os critérios de verdade ou falsidade, o que poderia nos lembrar, de certa forma, o pensamento de Kelsen. O que importa é a eficiência procedimental de seus resultados;

c. Parte de pressupostos antropológicos - livres de conteúdo metafísico - que concebem as pessoas como membros de uma sociedade política entendida como um sistema equitativo de cooperação social integrativa;

d. Dispensa, no seio do construtivismo político, em sua formulação da concepção política, o conceito de verdade. Com efeito, se tratamos de uma produção de objetos conforme a razão prática, recusando o conhecimento de alguns objetos dados pela razão teórica, o que estamos estabelecendo é que o critério de verdade permanece fora de uma formulação política construída procedimentalmente.

E a conclusão acerca desses traços fundamentais é dada pelo próprio Rawls, quando afirma que "todas estas estipulações, e outras mais, são necessárias para elaborar a ideia de que os princípios da justiça surgem de um adequado procedimento de construção social" 44 . Dessa maneira, o construtivismo político será explicado de acordo com uma concepção ${ }^{44}$ Ibid., p. 123. 
política de justiça cujos princípios serão selecionados pelas partes numa "hipotética posição original" 45 , em virtude dos interesses comuns includentes de todas as partes interessadas pela equidade social, em que o mesmo procedimento exige a razoabilidade das partes.

Mas convém alertar para não cairmos numa certa ingenuidade em relação ao construtivismo em geral e a tudo o que foi postulado por Rawls em particular. Não é possível começar do nada, mas algum material é necessário para começar. Segundo Rawls, "o procedimento em si é simplesmente fixado usando, como ponto de partida, as concepções básicas da sociedade em virtude dos interesses e da pessoa, os princípios da razão prática e o papel público desempenhado por uma concepção política de justiça" 46 . Dito de outra forma, nenhum construtivismo afirma, em sã consciência, que o essencialmente relevante é construído.

Em suma, a intenção de Rawls está voltada para a projeção e a construção de um modelo constitucional para uma sociedade democrática que paira acima dos interesses particulares, seja qual for sua origem, e que pode entrelaçar todas as partes num interesse comum politicamente orientado, desde uma concepção procedimental de justiça, que faz com que as partes, de um lado, co-impliquem-se cooperativamente na estrutura social e não se sintam marginalizadas ou desconsideradas pela fórmula jurídica genérica em que se amparam, visto ser este o produto de uma construção procedimental e não de uma concepção específica de mundo alheia à das partes.

O efeito final disso, segundo Rawls, é a geração de uma cultura pública apta a consolidar a práxis democrática das partes envolvidas, tido como algo emanado da própria sociedade democrática, e a preservar a possibilidade da pluralidade de critérios particulares - morais, religiosos, filosóficos -, de sorte que, portanto, para Rawls "o liberalismo político não é onicompreensivo ou abrangente" 47 .

É de suma importância, nesse momento, explicar a noção de "doutrina onicompreensiva" para Rawls: é todo critério religioso, moral e filosófico mediante o qual o ser humano compreende o mundo e suas consequentes relações. As doutrinas onicompreensivas ou abrangentes

\footnotetext{
45 Ibid., p. 134.

46 Ibid., p. 153-154.

47 Ibid., p. 23.
} 
compreendem aquilo que Habermas ou Heidegger chamam de discursos metafísicos e os autodenominados pós-modernos chamam de metahistórias ou metarrelatos.

Rawls considera que todos os cidadãos abraçam algumas dessas doutrinas, algo muito louvável, desde que seja entendido como uma forma pessoal de compreender as coisas e que não seja canalizado para um proselitismo social, porque dessa posição rumo ao engendramento das relações jurídicas ou políticas há um verdadeiro e intransponível abismo. Isso soa paradoxal, eis que o liberalismo moral, diferente do liberalismo político que nos ocupa aqui, também é onicompreensivo ou abrangente.

Consequentemente, o problema, em nossa ótica, insolúvel para Rawls, é que, inevitavelmente, as concepções políticas estão relacionadas, direta ou indiretamente, a uma doutrina onicompreensiva ou abrangente ${ }^{48}$. Mesmo assim, Rawls afirma que se deve "entender que o liberalismo político não é epistemológico nem metafísico" "49. As reivindicações do liberalismo político são, segundo ele, estritamente políticas, porque não se trata de estabelecer uma cosmovisão e nem mesmo um critério de verdade social ou política, mas de buscar reivindicações estritamente pragmáticas e funcionais.

$\mathrm{Na}$ verdade, Rawls vai muito mais longe, quando afirma que a sociedade democrática não demanda por doutrinas onicompreensivas, pois "a sociedade não tem objetivos ou propósitos finais como os que as pessoas e associações têm" 50 . E, de fato, uma sociedade democrática contempla e garante que as pessoas e as associações, dotadas de pretensões cunhadas pela razoabilidade e que nela se desenvolvem, possam alcançar tais fins com base em seus critérios estritamente particulares, e daí surge a salvaguarda da autonomia da sociedade democrática.

Entretanto, a sociedade como tal, o ente estatal e o aparato jurídico exigem uma imparcialidade que os afastem positivamente de tais doutrinas abrangentes, no que diz respeito à sua configuração procedimental. Comprometer a justiça e a ordem social com uma doutrina abrangente

\footnotetext{
48 Ibid., p. 42.

49 Ibid., p. 40.

50 Ibid., p. 72.
} 
implicaria, direta ou indiretamente, em cair na tentação injustificável de considerar essa doutrina uma verdade universal ${ }^{51}$. Por isso, o construtivismo político dispensará, em sua formulação política, do conceito de verdade, o que faz do construtivismo procedimental uma formulação que assegure a imparcialidade da justiça como equidade ${ }^{52}$.

A justiça como equidade apresenta a si mesma como uma concepção compartilhada de justiça e intentará relacionar todos os princípios comunitários e servirá de filtro institucional para examinar a justiça ou injustiça das instituições sociais e políticas que estabelecem o quadro da cooperação social. Seu objetivo é estritamente prático, pretendendo ser a base de um acordo político fundamentado, informado e voluntário.

Como princípio de operacionalidade procedimental do liberalismo político, a consideração da justiça como equidade deve ser completamente independente da multiplicidade de doutrinas abrangentes ou onicompreensivas ${ }^{53}$. Embora, seja preciso reconhecer, que tal consideração não surge do nada, mas se faz possível no campo da tolerância em sociedades democráticas consensuadas.

A ideia fundamental a que estamos a presenciar é a tendência de estabelecer as bases da cooperação social, como fundamento da interrelação entre os cidadãos, que são chamados a se entender graças a um conjunto de normas e procedimentos publicamente reconhecidos e concebidos, como efetivamente reguladores da sua conduta.

A equidade é justamente a categoria apropriada que estabelece as condições de possibilidade de a reciprocidade ser benéfica entre as partes, na medida em que os resultados serão benéficos para todos. Isso implica certa noção de vantagem racional ou bem para cada participante que está imerso na dimensão da justiça como equidade e trabalha cooperativamente, sem perder a referência em seu próprio benefício, como sujeito autônomo ${ }^{54}$.

${ }^{51}$ Resta saber se podemos conceder o benefício da dúvida quanto às doutrinas onicompreensivas seculares que buscam entrar no jogo político como uma espécie de dogma, no sentido de que se erigem como condição sine qua non da própria democracia, entendida de maneira laica, mas que, ao cabo, na prática, enveredam para uma comunidade laicista.

52 Ibid., p. 73 e 125.

53 Ibid., p. 39-40.

54 Ibid., p. 46. 
$\mathrm{Na}$ visão antropológica de Rawls, cada pessoa é um cidadão, alguém que recebe sua identidade da sociedade em que está imerso e na qual é um cooperador durante todo o ciclo de sua vida ${ }^{55}$ e cujas faculdades morais revelam duas capacidades ${ }^{56}$ :

a. O sentido de justiça que lhe permite compreender, aplicar e agir de acordo com o senso de justiça equitativo que condiciona a cooperação social.

b. O sentido do bem, como capacidade racional para o próprio proveito.

O método de captação do senso tradicional de justiça, numa sociedade equitativa de cooperação social, entre cidadãos livres e iguais, é o que se chama de "posição original". Supõe um ponto de vista distanciado das características e circunstâncias particulares com respeito ao pano de fundo global. O objetivo é captar conceitualmente os valores de igualdade e liberdade de forma a calibrar qual seria o acordo que as partes representativas dos cidadãos poderiam chegar.

Nesse sentido, a posição original tem a dupla funcionalidade de ser um mecanismo de reflexão pública e de autoqualificação ${ }^{57}$. Mas a posição original não opera por si mesma, mas junto ao chamado "véu da ignorância". Este é um dos conceitos mais recorrentes na exata medida em que se mostra como um dos menos explícitos.

Pelo que podemos dizer a partir dos contextos em que é utilizado, é uma ocultação intencional da visão compreensiva das partes que, em virtude de uma boa vontade para se chegar a um consenso cooperativo equitativo, permite o esquecimento - no processo de alcance da justiça como equidade - das compreensões particulares de caráter moral, filosófico ou religioso.

Como a posição original é um mecanismo de representação social, podemos descrever o processo claramente da seguinte forma:

\footnotetext{
55 Ibid., p. 48.

56 Ibid., p 49-135.

57 Ibid., p. 52.
} 
a. as partes, nesta posição, são descritas como representantes racionalmente autônomos da cidadania, chamadas a defender, da melhor forma possível, seus representados, e sempre submetidas às restrições da posição original;

b. O véu da ignorância significa que as partes desconhecem a posição social ou a concepção de bem e mesmo as capacidades realizadas e tendências psicológicas;

c. Como efeito, as partes devem chegar a um acordo, a partir de uma breve lista de alternativas procedentes da tradição da filosofia moral e política, acerca de determinados princípios de justiça;

d. O acordo das partes para definir os princípios de justiça estabelece um elo entre esses princípios e o conceito de pessoa representada pela posição original ${ }^{58}$.

Ao longo desse processo, no qual se estabelece uma forma de conhecimento a respeito do tecido político da sociedade democrática, de acordo com a ideia de justiça como equidade, três pontos de vista podem ser destacados:

a. o das partes na posição original;

b. o dos cidadãos na sociedade bem ordenada;

c. o dos estudiosos da justiça como equidade ${ }^{59}$.

58 Um dos pontos que mais nos impressiona é o da representação das partes na posição original. Rawls insiste continuamente que a justiça como equidade é uma forma democrática que afeta indivíduos autônomos. É por isso que, para ele, é conveniente dispensar doutrinas onicompreensivas ou abrangentes. Além disso, como veremos à medida que avançamos nesse ensaio, é responsabilidade pessoal de cada cidadão casar sua doutrina abrangente com a justiça como equidade. Associações, partidos e sociedades intermediárias - os representantes que protagonizam o gozo do princípio da subsidiariedade - não são os meios apropriados para uma concepção de sociedade democrática em Rawls. Por que ele recorre, então, a uma representação da cidadania estruturada em partes na posição original? Por que o véu da ignorância é exercido pelas partes em relação aos representados e não diretamente por cidadãos autônomos que desejam estar co-implicar-se na sociedade democrática?

59 A dúvida reside, justamente, em não sermos capazes de distinguir bem entre os dois primeiros pontos de vista. Ambos pertencem à justiça como equidade. O curioso de Rawls é o reconhecimento das partes como "criaturas artificiais que habitam nosso mecanismo de representação".Aqui, uma dúvida séria surge novamente: que necessidade há de distinguir entre a cidadania de uma sociedade bem ordenada e o artifício representativo? Será que, na justiça como equidade, os cidadãos também ficam à margem de sua elaboração? 
É claro que nossa perspectiva analítica é decisiva, como forma avaliativa de justiça como equidade. É a perspectiva que nos permite reificar as duas primeiras e nos colocar num plano distante como teóricos ou estudiosos. Ora, convém dar outro passo a mais na configuração conceitual que estamos estabelecendo, para falar do consenso sobreposto como a aspiração máxima de uma política independente que busca a justiça como equidade.

Trata-se, inicialmente, de uma questão especulativa, uma conjectura baseada no fato de que a permanência das doutrinas onicompreensivas dotadas de razoabilidade atrairão, em sua permanência geracional, a adesão ao regime constitucional. O consenso sobreposto, um ponto chave para a compreensão da justiça como equidade, é, precisamente, o que a salvaguarda de um indiferentismo cético em relação à verdade política e, se deve haver tal categoria, ela se fundamentaria na medida em que "partimos do pressuposto de que cada cidadão afirma uma concepção desta natureza e esperamos que todos possam aceitar uma concepção política como verdadeira do ponto de vista da sua própria doutrina compreensiva, seja ela qual for" 60 .

Neste sentido, a verdade política torna-se a base da unidade social. Portanto, a constituição de uma coesão social que promova a justiça como equidade, no consenso sobreposto, conta sempre com um critériochave no estudo de Rawls: a razoabilidade. A distinção entre o racional e o razoável é central para nossa concepção de liberalismo político. Para começar, partamos do princípio de que esses são dois conceitos independentes de justiça como equidade.

Comecemos com o racional, termo que se aplica a um agente singular e unificado -individual ou coletivo - dotado de capacidades suficientes para perseguir os interesses particulares que lhes são próprios. Racional se aplica à forma como esses interesses são abraçados e afirmados, bem como a forma como são priorizados.

As pessoas são razoáveis num aspecto básico quando, sendo, digamos, iguais, estão dispostas a propor princípios e critérios como termos equitativos de cooperação e a aceitá-los de boa vontade, desde que tenham a garantia de que outros farão o mesmo. A razoabilidade é um elemento da ideia de sociedade como um sistema de cooperação equitati-

${ }^{60}$ Ibid., p. 182. 
va e desde que seus termos equitativos sejam razoáveis para todos faz parte de sua noção de reciprocidade ${ }^{61}$.

A razoabilidade não é uma ideia epistemológica, mas faz parte do ideal democrático das razões públicas e relativiza as doutrinas abrangentes ou onicompreensivas. A razoabilidade, como vimos no parágrafo anterior, é pública e pela razoabilidade entramos no coração da esfera social ${ }^{62}$.

A razão pública deve ser entendida como a razão de cidadãos iguais que, como um ente coletivo, exercem o poder político, legislando e melhorando sua constituição. Seus limites não se aplicam às nossas deliberações políticas pessoais, mas apenas no quadro de um compromisso de competência regulada nos fóruns públicos de debate ${ }^{63}$.

Em última análise, tudo isso implica um ideal de cidadania que nada mais é do que liberdade e igualdade. Isso decorre da busca insistente desse ideal, com base no liberalismo político, entendido pela justiça como equidade. Liberdade e igualdade são dois pressupostos a partir dos quais partimos em uma sociedade democrática.

As co-implicações da estrutura em que entramos não apenas revelam que partimos dessa ideia, mas que chegamos a ela como a reivindicação final para salvaguardar a autonomia pessoal. Essa autonomia plena, captada pela forma de relacionamento das partes ${ }^{64}$, dá-nos a ideia de que a própria concepção não só não é construída ${ }^{65}$, mas também determinante da forma do procedimento político ${ }^{66}$.

O que resta para o cidadão fazer na democracia procedimental de Rawls? Muito. A liberdade do cidadão fica comprometida com sua própria responsabilidade no processo de cooperação razoável inspirado na justiça como equidade. E isso porque o cidadão fica com um desafio absolutamente radical e decisivo na criação, não de uma sociedade demo-

\footnotetext{
61 Ibid., p. 80.

62 Ibid., p. 91 e 93.

63 Ibid., p. 288.

64 Ibid., p. 108.

65 Ibid., p. 139.

${ }^{66}$ Ibid., p. 134.
} 
crática como uma estrutura política, mas como uma cultura compartilhada, que forja aquela compreensão de Dewey da democracia como um modo de vida ${ }^{67}$.

Os cidadãos relacionarão livremente os valores políticos da sociedade democrática com suas próprias doutrinas onicompreensivas ${ }^{68}$. Com isso, Rawls deixa nas mãos da consciência pessoal a possibilidade não só de se adaptar livre e conscientemente à possibilidade de uma política democrática cooperativa e compartilhada, mas que a estrutura básica, que inicialmente vimos como o primeiro objetivo da justiça como equida$\mathrm{de}^{69}$, afeta os indivíduos, na medida em que cria uma certa forma de cultura compartilhada ${ }^{70}$.

Daqui, talvez, o discurso sobre a construção de uma constituição democrática rumo a um determinado entendimento cultural escape às pretensões estritamente políticas de Rawls e, por isso, convém começar a discernir com Habermas a possibilidade de uma convivência distinta e abrangente.

${ }^{67}$ Dewey diz, em Democracia e Educação, que a democracia constitui um princípio educativo. Para ele, isso significa que um governo que se funda no sufrágio popular somente pode ser eficiente se os que o elegem e obedecem são educados para isso, ou seja, se têm acesso ao instrumental de informações que adequadamente lhes permitirá a atuação como cidadãos democráticos. No entanto, para Dewey, uma democracia é muito mais que uma forma de governo; é, primeiramente, uma forma de vida associada, de experiência conjunta e mutuamente comunicada. $\mathrm{O}$ autor ressalta que se refere apenas em menor grau à participação dos cidadãos nas eleições e muito mais à ideia de que a democracia faz recair em nós a responsabilidade de considerar o que desejamos como indivíduos e quais são nossas necessidades e preocupações. Da mesma forma que a democracia exige que, no jogo político, cada indivíduo forme suas convicções, expresse-as e tenha a oportunidade de fazer com que as mesmas influam nos rumos do governo, cada pessoa somente é educada no sentido de Dewey quando, além do contato com o livro-texto e com a fala do professor, tem a oportunidade de contribuir para o processo educativo com sua própria experiência pessoal. Assim como a educação está em relação íntima com a democracia, esta não consegue se desenvolver sem aquela, porque a escola é o agente especial de distribuição dos valores e finalidades de um grupo social e, se não estiver aliada à forma democrática, representará uma ameaça a ela.

68 Ibid., p. 172.

69 Ibid., p. 293.

70 Ibid., p. 305. 


\section{Habermas x Rawls}

Destacadas as ideias de cada um desses pensadores, acreditamos ser oportuno expor o debate em que esses autores de tamanha envergadura estão envolvidos no pensamento contemporâneo, porque cada um tem origem em diferentes tradições, como a filosofia moral de inspiração analítica (Rawls) e a filosofia neomarxista da Escola de Frankfurt (Habermas) e, como efeito, tentaremos coletar, com igual interesse, as objeções de Habermas à proposta de Rawls e, depois, as respostas do filósofo americano ao colega alemão.

De acordo com a crítica inicial de Habermas, Rawls estabeleceu um ponto de ruptura com a filosofia prática em sua Teoria da Justiça, na qual, em oposição ao utilitarismo e ao ceticismo, propõe uma leitura intersubjetiva do conceito kantiano de autonomia, que Rawls maneja como chave de compreensão da autonomia política dos cidadãos de um Estado de Direito $^{71}$.

Rawls reage contra o contextualismo, que parece contrário ao entendimento de uma razão comum a todos os seres humanos, louvável e compartilhada por Habermas. Mas este último questiona se Rawls é capaz de afirmar suas intuições normativas de forma mais convincente.

Rawls lastreia os princípios diretores de uma sociedade moderna na liberdade e na igualdade das pessoas. Para isso, ele recorre à explicação do que tem sido chamado de posição original do liberalismo político que supõe a concordância de todas as partes em torno de dois princípios:

a. O princípio liberal, segundo o qual, todos têm igual liberdade de ação subjetiva;

b. Subordinado ao anterior, um marco regulatório que assegure a igualdade de acesso às funções públicas, o que implica para Rawls que as desigualdades são aceitáveis apenas em benefício dos menos privilegiados.

Para Rawls, o liberalismo político é um constructo racional que não reivindica pretensões de verdade, o que lhe confere uma posição de neutralidade em relação às concepções de mundo. O desenho da posição origi-

${ }^{71}$ John Rawls, Uma Teoria da Justiça, 3. ed. (São Paulo: Martins Fontes, 2008), 41. 
nal levanta para Habermas a seguinte questão: ela é adequada para uma explicação deontológica dos princípios da justiça?

A posição original é a situação em que os representantes racionais da cidadania decidem, sob estritas limitações que garantam um julgamento imparcial, sobre questões de justiça. Trata-se de uma concepção de autonomia reservada para quem já vive no quadro das instituições de uma sociedade bem ordenada e que se compõe de dois elementos:

a. propriedades neutras das partes que buscam sua vantagem racional;

b. restrições normativas: ser racional, negociar com base na concepção do bem de cada um e com interesse na racionalidade.

Mas Habermas questiona se as partes, na posição original, podem representar os interesses preferidos de seus constituintes com base em seu egoísmo racional?

É insustentável, pois, que o cidadão autônomo seja representado por uma parte não autônoma. Os cidadãos, por hipótese, são "pessoas morais", o que os implica em ideais onicompreensivos, em questões de sentido de justiça, capacidade para sua própria concepção de bem e no interesse por cultivar a racionalidade.

$\mathrm{Na}$ posição original, as partes são liberadas dessas implicações morais por um projeto objetivamente racional. A eleição racional supõe, para Habermas, uma eleição moral. Portanto, o desenho teórico-decisório de Rawls implica na introdução de bens básicos à vida ${ }^{72}$.

Habermas ainda questiona se os direitos básicos podem ser assimilados aos bens básicos. Colocamo-nos na posição de atores que atuam na primeira pessoa. Isso significa que as questões normativas, sejam de interesses ou valores, só são satisfeitos por meio de bens: o que aspiramos, o que é bom para nós.

Para Rawls, de acordo com Habermas, os bens básicos são um direito. A questão está em ver os princípios da justiça como justiça distributiva, o que implicaria vê-los na perspectiva de uma ética dos bens (seja aretaica ou utili-

72 John Rawls e Jurgen Habermas, Debate sobre el liberalismo político (Barcelona: Paidós, 1998), p. 45-47. 
tária), que difere da teoria do direito baseada na autonomia. É assim, na medida em que os direitos só podem ser usufruídos quando são exercidos.

Portanto, eles só se tornam possíveis quando aqueles que gozam de direitos se reconhecem mutuamente como livres e iguais. Os direitos regulam as relações, e não só posses. É por isso que a liberdade não é um "direito básico", mas um "bem básico". As normas, por sua vez, supõem:

a. a satisfação de expectativas de comportamento generalizado com a pretensão de validade binária ( $\operatorname{sim} /$ não);

b. só nos permitem sim, não ou abster-se;

c. não podem ser contrariadas se se dirigem aos mesmos destinatários;

d. exigem a formação de um sistema;

e. fazem relação a um tipo diferente de ação;

f. são diferentes dos critérios de coesão social.

Os valores são ações dirigidas a um fim, e Habermas vê nisso uma contradição ontológica entre direitos e bens. Mas Habermas não termina por aí, e questiona se o véu da ignorância garante a imparcialidade do juízo. A capacidade de tomar decisões racionais não é suficiente para representar os interesses dos representados, nem para entender os direitos como trunfo que prevalecem sobre todo o fim coletivo.

Para Habermas, Rawls evitaria problemas se desenvolvesse o modo procedimental de forma consequente, porque não podemos partir de uma cosmovisão universalmente válida que implique, depois, um pluralismo social e de visões de mundo. A ética discursiva se apoia na intuição de que o princípio da universalização implica a assunção ideal de um rol conjunto de valores.

Outra coisa é que, na posição original, o véu de ignorância inicialmente restringe o campo de visão das partes aos princípios sobre os quais os cidadãos presumivelmente livres e iguais estariam de acordo - não obstante suas divergências -, o que significaria a possibilidade de se estender a todos os pontos de vista e interesses particulares que alteram um julgamento imparcial, ou apenas ao conteúdo normativo. 
A partir da restrição de perspectivas, constrói-se a perspectiva ideal ampliada de um nós que é diferente da posição original e, logo, segundo Habermas, o véu da ignorância restringe o campo de visão e do conhecimento da realidade. Até agora, vimos apenas pontualizações críticas que Habermas faz acerca da teoria de justiça de Rawls. Em suma, Habermas diz que, para a fundamentação dos princípios superiores, ou seja, a liberdade e a igualdade, as negociações decidem menos na posição original do que em suas próprias instituições e conceitos básicos de construção.

Assim, Rawls irá introduzir, no procedimento de fundamentação, conteúdos normativos relacionados com o conceito de pessoa moral, incluindo o conceito de colaboração equitativa entre cidadãos autônomos. Habermas infere daqui o interesse de Rawls em formular uma concepção política e não metafísica de justiça.

A partir daqui, Habermas questiona o consenso sobreposto: ele desempenha uma função cognitiva ou instrumental? Em que sentido Rawls usa o qualificativo "razoável”? O equilíbrio reflexivo implicaria aprimorar o conceito de pessoa moral, mas temos que, no liberalismo político, o conceito de pessoa deve ser mostrado neutro de tal forma que seja aceitável para todas as doutrinas abrangentes ou compreensivas.

Isso implica numa nova apreciação do desenvolvimento intelectual de Rawls, que, segundo Habermas, não quer distinguir as questões de fundamentação daquelas de aceitabilidade. Consequentemente, o efeito socialmente estabilizador do consenso sobreposto é explicado mediante uma confirmação cognitiva do suposto de que justiça como equidade seja entendida de forma neutra pelas doutrinas abrangentes ou onicompreensivas $^{73}$.

John Rawls ficará interessado em responder à abordagem de Habermas a partir da seguinte questão: qual a relação das doutrinas abrangentes $^{74}$ no seio do consenso sobreposto com a fundamentação da concepção política, na medida em que os cidadãos considerem essa concepção como razoável e independente?

\footnotetext{
73 Ibid., p. 54-59.

${ }^{74}$ Ibid., p. 89.
} 
Com base nisso, Rawls exporá três tipos de justificativa e dois de consenso no liberalismo, cuja tipologia resumiremos esquematicamente da seguinte forma:

a. Justificativa pro tanto: nos argumentos de razões públicas, a justificativa de razão política leva em consideração apenas os valores políticos e, na suposição de Rawls, uma concepção política adequadamente completa. Ou seja, os valores políticos a ela vinculados podem ser convenientemente ordenados ou equilibrados, de modo que somente esses valores deem uma resposta razoável por meio de argumentos de razões públicas a todas ou quase todas as questões relativas às questões constitucionais essenciais e à justiça básica. Essa justificativa política é dispensável por parte das doutrinas abrangentes ou onicompreensivas;

b. Justificativa plena: será realizada por um cidadão individual como membro de uma sociedade civil. Nesse caso, ele aceita uma concepção política e a insere de alguma forma em sua doutrina compreensi$\mathrm{va}^{75}$, seja a partir da consideração de que é algo verdadeiro, seja considerando que se trata de algo razoável, mas sempre condicionado à doutrina abrangente do cidadão em questão;

c. Justificativa pública na sociedade política: temos aqui que a ideia básica do liberalismo político funciona em combinação com três outras, a saber, o consenso sobreposto, a estabilidade para as razões justas e a legitimidade. Temos esta justificação no caso de todos os membros razoáveis da sociedade política fundamentarem a concepção política compartilhada, incorporando-a em suas concepções abrangentes razoáveis e, nesse caso, dependendo deste última apenas indiretamente. Dentro desta justificativa pública, inclui-se a tarefa de mostrar estabilidade por razões justas, o que implica a legitimação de uma ação coercitiva do governo ${ }^{76}$.

A estabilidade por razões justas é explicada da seguinte maneira:

a. a estrutura básica da sociedade é efetivamente regulada de acordo com a concepção política da justiça mais razoável;

\footnotetext{
75 Ibid., p. 90.

76 Ibid., p. 91-95.
} 
b. esta concepção política é confirmada por um consenso sobreposto, formado por todas as doutrinas abrangentes razoáveis na sociedade e estas constituem uma maioria permanente no que diz respeito aos que a rejeitam;

c. as dimensões políticas públicas, no caso de elementos constitucionais e questões básicas de justiça, são sempre (ou quase sempre) passíveis de decisão com base nas razões especificadas pela concepção política mais razoável de justiça ou por uma família razoável de tais concepções ${ }^{77}$.

Segundo Rawls, visto que a concepção de política de justiça acima exposta é a mais razoável ou, pelo menos, é sustentada por doutrinas abrangentes razoáveis, esta concepção seria a base mais razoável para a unidade social. Ademais, do fato de que as doutrinas abrangentes estão envolvidas nessa concepção política de justiça, infere-se a grande profundidade da justiça, pois representam as convicções mais arraigadas da cidadania.

Portanto, podemos ver como Rawls não desconsidera as crenças particulares de grupos ou indivíduos, mas, precisamente, coloca nelas a possibilidade de uma fundamentação da concepção política de justiça, na medida em que ditas crenças ou doutrinas, entre as quais estão aquelas de origem religiosa, incorporem o procedimentalismo democrático em uso à sua própria idiossincrasia.

Dado que a justificativa pública é sempre pro tanto, como a justificativa pública da concepção política de justiça pode ser verificada? Aqui, Rawls apresenta a necessidade da existência e do conhecimento de um consenso sobreposto razoável. Em seguida, resta notar que a ideia de legitimidade pressupõe o entendimento de cidadãos razoáveis aplicado à estrutura geral da autoridade política, o que exigiria a criação de uma Constituição que pode ser compartilhada por todos os cidadãos razoáveis, que se baseiam nos princípios básicos da liberdade e da igualdade ${ }^{78}$.

Com isso, Rawls quer responder à primeira parte da pergunta que ele mesmo fez a Habermas. No entanto, Habermas não parece satisfeito com essas indicações quando, em sua refutação a Rawls, faz as seguintes

77 Ibid., p. 96.

78 Ibid., p. 97-98. 
observações. Habermas entende que, pelo fato de o consenso sobreposto resultar do controle simultâneo, mas singular da cidadania, embora esse controle da aceitação pessoal funcione, os critérios aplicados correspondem a interesses particulares.

Como feito disso, não podemos falar, então, de um argumento de razões públicas sobre o consenso sobreposto, mas sim do que Frost chamou de "uso privado da razão com propósitos políticos e públicos"'79. Se com isso Habermas pretende aludir ao risco, por outro lado justificado em qualquer arcabouço institucional, de alteração da ordem dos interesses públicos, na justificação do consenso sobreposto que ocorre na justiça como equidade, a resposta de Rawls não deixa dúvidas quando afirma ser precisamente a constituição, emanada da justiça como equidade, que impõe limites à legislação parlamentar como disciplina e regulação do orçamento, poder coercitivo estatal ${ }^{80}$.

Ele então responderá à hesitação de Habermas sobre o significado que Rawls confere ao qualificativo "razoável": um qualificativo de validade de máximas morais, ou um qualificativo para a atitude reflexiva de tolerância esclarecida. Habermas viu que Rawls formulará uma teoria da justiça, que não pode ser verdadeira ou falsa, porque os enunciados normativos não reproduzem uma ordem de fatos morais independentes de nós.

Rawls apresenta o qualificativo "razoável" como um contraconceito ao de "verdadeiro" para garantir enunciados normativos e a teoria da justiça como um todo, considerando o caráter vinculante que se baseia no reconhecimento intersubjetivo, mas ao qual não é concedido um significado epistêmico ${ }^{81}$.

Nas considerações de Habermas, Rawls introduz o conceito de "razoável" como propriedade de pessoas morais que têm senso de justiça e estão numa disposição cooperativa equitativa, cientes da falibilidade de seus critérios e, ainda assim, dispostas a justificar sua concepção de justiça política ${ }^{82}$.

\footnotetext{
${ }^{79}$ Ibid., p.167.

80 Ibid., p. 121.

81 Ibid., p. 59.

82 Ibid., p. 60.
} 
Na tréplica de Rawls, as doutrinas abrangentes razoáveis são igualmente importantes no consenso sobreposto, de modo que a concepção política de justiça pode ser verdadeira em sua compatibilidade com tais doutrinas abrangentes. Nesse sentido, Habermas aponta que, então, a concepção política de justiça ${ }^{83}$ continua a ter pretensões de verdade. A resposta de Rawls é enfática: “O liberalismo político não emprega o conceito de verdade moral aplicado a seus próprios julgamentos políticos (sempre morais). Afirma tão somente que os julgamentos políticos são razoáveis ou não razoáveis e expõe os ideais, princípios e padrões políticos como critérios de razoabilidade" 84 .

A categoria de verdade não é questionada ou rejeitada em relação às doutrinas abrangentes - como já vimos - mas o liberalismo político, considerando a ideia de razoável como suficiente, mantém seu esquema procedimental, o que lhe confere a independência e as possibilidades que entram em suas perspectivas construtivistas de uma concepção política de justiça.

Para Rawls, a alegação de Habermas de que o liberalismo político não pode evitar a questão da verdade e da compreensão filosófica da pessoa, não parece exigir mais justificativa teórica do que o fato de terem sido substituídos pelos conceitos de razoável e de cidadãos livres e iguais ${ }^{85}$. A esta altura do debate, Rawls não parece ter mais intencionalidade para disputar nesse sentido, dando lugar a outras questões que não pretende deixar sem resposta.

Nesse sentido, Rawls tomará a nova base de referência para estabelecer critérios em defesa da posição original, como integradora dos direitos e das liberdades dos antigos e modernos. Quanto mais se levanta o véu da ignorância e mais assume uma forma real de carne e osso, os cidadãos de Rawls encontram-se mais profundamente imersos na hierarquia de uma ordem progressivamente institucionalizada acima de suas cabeças.

Assim, a teoria tira dos cidadãos boa parte daquelas intuições que cada geração teria que voltar a fazer como suas. Do ponto de vista da teoria da justiça, o ato fundador do Estado de Direito não pode e nem precisa se repetir nas condições de uma sociedade já ordenada de maneira

\footnotetext{
83 Ibid., p. 61-63.

${ }^{84}$ Ibid., p. 99.

85 Ibid., p. 100.
} 
justa e o processo de realização dos direitos não precisa ser questionado no longo prazo. Os cidadãos não podem vivenciar esse processo, pois a mudança das condições históricas exigiria, entretanto, sempre um processo aberto e inacabado.

Eles não podem reiniciar a ignição do núcleo democrático radical da posição original na vida real de sua sociedade, visto que, a partir de sua perspectiva, todos os discursos de legitimação essenciais ocorreram dentro da teoria e os resultados dos debates teóricos já estão fixados no marco constitucional. Uma vez que os cidadãos não podem entender a lei constitucional como um projeto, o uso público da razão não tem propriamente o significado de um exercício atual de autonomia política, mas apenas serve à manutenção pacífica da estabilidade política.

Essa leitura certamente não reproduz a intenção que Rawls atribui à sua teoria, mas revela, se somos capazes de entendê-la corretamente, uma de suas consequências indesejadas. Isso é evidenciado, por exemplo, na fronteira rígida entre a identidade política e a identidade não pública dos cidadãos. Segundo Rawls, essa fronteira é traçada por direitos liberais básicos, que limitam a autorregulação democrática e, com ela, a esfera do político desde o início, ou seja, anterior a qualquer formação política da vontade ${ }^{86}$.

Rawls argumenta que parece haver um mal-entendido em Habermas a respeito do que ele chama de uma sequência em quatro estágios, que não descreve um processo político efetivo, nem teórico, mas se constitui, na justiça como equidade, dentro de uma baliza de pensamento para os cidadãos da sociedade civil, interessados em aceitar a justiça como equidade, buscando aplicar seus conceitos e princípios.

Dita sequência é estabelecida da seguinte forma:

a. Posição original onde as partes escolhem os princípios da justiça;

b. Convenção constitucional onde, considerando-nos delegados, deveríamos elaborar os princípios e regras de uma Constituição, em virtude dos princípios de justiça que já temos;

86 Ibid., p. 66-67. 
c. Tornamo-nos legisladores, que a constituição admite e que os princípios da justiça exigem e permitem;

d. Assumimos o papel de juízes quando interpretamos a lei constitucional.

A tudo isso, deve-se dizer ser a posição original aplicável em cada caso e se requer, para tal desiderato, a informação relevante que garanta nossa imparcialidade. Por outro lado, as instituições administrativas são criações geracionais transmitidas à medida que crescemos nelas. Portanto, é enfatizado que os princípios não podem ser mantidos perpetuamente, pois estes, por assim dizer, sobrevivem numa sociedade civil viva e dinâmica sujeita a julgamentos reflexivos.

Mas é muito importante considerar que as leis decorrentes desse arcabouço não podem ser alteradas arbitrariamente, sem o risco de condicioná-las aos nossos interesses racionais privados. Portanto, no liberalismo político, a autonomia é entendida como política e não como moral, razão pela qual se concreta nas instituições e práticas políticas, bem como na intenção de efetivar um regime constitucional ${ }^{87}$.

Rawls ainda considera a perspectiva da cidadania no contexto cultural, partindo do pressuposto de que na fase da convenção constitucional, após terem sido escolhidos os princípios da justiça na posição original, é adotada uma lei constitucional que, com sua declaração de direitos e demais dispositivos, restrinja a legislação majoritária na medida em que englobe as liberdades básicas (consciência, expressão e pensamento).

Tal restrição garante que as liberdades básicas não fiquem a critério de uma etapa pré-política, na justiça como equidade. Consequentemente, são a liberdade e a vontade popular expressas em procedimentos democráticos que ratificam uma Constituição, porque, para Rawls, a proteção constitucional dos direitos básicos não é um artifício anterior a que Habermas chamará de formação da vontade, mas, antes, "a sequência dos quatro estágios justapõe-se, portanto, na ideia de que as liberdades dos modernos estão sujeitas à vontade constitucional do povo" 88 .

A seguir, a réplica de Habermas situa-se na esfera teórica de uma "competição não resolvida entre as liberdades dos antigos e as liberdades dos modernos" ou, em outras palavras, entre a autonomia pública e pri-

${ }^{87}$ Ibid., p. 103.

88 Ibid., p. 110. 


\title{
vada $^{89}$. Para bem delimitar o problema, transcrevemos o respectivo tre- cho dessa réplica, em que Habermas mostra que
}

\begin{abstract}
os primórdios da doutrina dos direitos subjetivos caracterizaram-se por uma espécie de autonomização normativa dos direitos subjetivos de conteúdo moral que pretendiam ter uma legitimidade superior àquela concedida pelo processo político de produção normativa. Seu senso de liberdade garantido emprestaria aos direitos subjetivos uma autoridade moral independente da produção democrática do direito, uma autoridade moral que não poderia ser fundada dentro da própria teoria do direito. A reação a isso foi uma evolução cujo ponto final foi a subordinação abstrata dos direitos subjetivos à lei objetiva, subordinação na qual a legitimidade de uma dominação política é entendida em termos de "positivismo da lei". Mas o curso dessas discussões esconde o problema real que a posição central dos direitos subjetivos privados acarreta: não é possível explicar de onde o direito positivo recebe sua legitimidade. Certamente, a fonte de toda legitimidade está no processo democrático de produção da lei e esse processo, por sua vez, apela ao princípio da soberania popular. Ora, o "positivismo do direito" não introduz esse princípio de maneira a preservar o conteúdo moral autônomo dos direitos subjetivos - a proteção da liberdade individual que Coing enfatiza. De uma forma ou de outra, portanto, fica cerrado o significado intersubjetivo das liberdades subjetivas de ação legalmente conferidas e, com isso, uma relação entre autonomia privada e autonomia pública em que ambos os momentos poderiam ser afirmados sem cortes ou perdas ${ }^{90}$.
\end{abstract}

$\mathrm{Na}$ verdade, Rawls está correto ao apontar que, de acordo com Habermas, tanto os escritores liberais quanto os republicanos não consegui-

${ }^{89}$ Esta é uma questão que muito preocupa Habermas (1997:28): “A autonomia que, por assim dizer, no campo moral se faz uma só, no campo jurídico surge na dupla figura da autonomia privada e pública. Esses dois momentos devem ser mediados de forma que uma autonomia não prejudique a outra. As liberdades subjetivas de ação do sujeito privado e a autonomia pública dos cidadãos são mutuamente possíveis. Estas são acomodadas pela ideia de que as pessoas só podem ser autônomas na medida em que o exercício de seus direitos de cidadania pode ser entendido como autores cumpridores dos direitos aos quais devem obedecer. A soberania popular é identificada com a liberdade dos antigos e os direitos humanos com a dos modernos".

90 Ibid., p. 154-155. 
ram entender a relação interna entre autonomia pública e autonomia privada, esta última sendo especificada de acordo com as liberdades dos modernos, fundadas nos direitos humanos baseados no império da lei. Ao negar ao direito natural os direitos dos modernos, mas considerandoos baseados na moralidade, o liberalismo subordinaria a ordem jurídica a um fundamento externo, limitando o direito democrático legitimado, que corresponde à posição de Ratzinger em oposição a isso.

Para Rawls, então, a questão seria resolvida descobrindo-se a conexão interna entre as duas formas de autonomia, o que colocaria um fim na "competição não resolvida", dado que se verificaria que ambas as autonomias pressupõem-se mutuamente, se forem plenamente conquistadas numa democracia harmonizada e equilibrada ${ }^{91}$.

Assim, os direitos humanos, uma vez assimilados na coerção e a sanção estatais, não podem ser considerados como um agente externo. Os direitos humanos fariam parte dos próprios princípios constitucionais adotados pela Lei Maior. O suposto dilema é que, enquanto os direitos humanos não podem ser impostos externamente no exercício da autonomia política num regime democrático, essa autonomia, por maior que seja, não pode violar esses direitos por meio de suas leis sem prejudicar a legitimidade.

No próximo passo, Rawls negará, de maneira categórica, que o liberalismo deixe sem solução a suposta competição entre autonomia pública e privada, em virtude da correção de ambas as posições. Rawls não perde a oportunidade de considerar que, no liberalismo bem compreendido, ou seja, o da justiça como equidade, é justamente isso que mostra essa conexão interna ${ }^{92}$.

Habermas não o considerará assim, porque a condição de cidadão democrático só pode ser institucionalizada com o auxílio do direito coercitivo e, sem isso, surge uma tensão que impede a assunção do status de pessoa: "Não existe nenhum direito sem as liberdades subjetivas de ação reivindicáveis juridicamente que assegurem a autonomia privada das pessoas" ${ }^{\prime 3}$.

\footnotetext{
91 Ibid., p. 117.

92 Ibid., p. 118.

93 Ibid., p. 70.
} 
Rawls insistirá que as liberdades dos antigos e dos modernos são cooriginárias, sem qualquer preeminência de uma sobre a outra e que ambas têm suas raízes na capacidade para a justiça e na capacidade de compreensão do bem, faculdades essas que não são hierarquizadas e que implicam uma concepção política da pessoa. Consequentemente, a aceitação da justiça como equidade implica a utilização da posição original como mecanismo representativo e determinante dos direitos da cidadania, reconhecidos em igualdade ${ }^{94}$.

Por fim, John Rawls direcionará seu discurso no sentido de defender o procedimentalismo da justiça como equidade, questionado por Habermas, que o considerará substantivo. Nessa linha, o primeiro ponto consistirá em distinguir os conceitos, resultando na substantividade como o resultado próprio e específico da justiça como equidade. Nesse sentido, não se trata de renunciar à substantividade que, por outro lado, Rawls também vê em Habermas.

A questão é que a justiça do procedimento é relativa ao resultado deste mesmo ${ }^{95}$. A procedimentalidade da justiça como equidade não pode ser, portanto, questionada. Em qualquer caso, o modelo concreto de procedimentalismo dependerá dos resultados da justiça. Consequentemente, podemos afirmar que a justiça procedimental depende da justiça substantiva, mas deve-se considerar, com isso, que apenas se resolve um problema de nuance em relação à legitimidade do que se considera legal ou democrático.

$\mathrm{Na}$ verdade, a substantividade reforça e efetua a justiça como equidade. A razão explicativa de Rawls é que o conceito de legitimidade, tão demandado por Habermas, não predica mais do que sua procedência. Desse modo, um certo procedimentalismo político pode legitimar um arcabouço constitucional, ao mesmo tempo em que nada diz sobre ser ou não justo. A justiça como equidade estabelece-se, assim, por meio de um procedimento, qual seja, o do consenso sobreposto que sempre requer uma concepção substantiva de justiça, ou seja, que atenda ao resultado desse consenso, ao mesmo tempo que se qualifica como justa per se.

\footnotetext{
94 Ibid., p. 124.

95 Ibid., p.128-129.
} 
Segundo Rawls,

em algum momento, a injustiça dos resultados de um procedimento democrático legítimo corrompe sua legitimidade e isso traz a injustiça da própria constituição política. Mas antes de chegar a este ponto, os resultados de um procedimento legítimo são legítimos, sejam eles quais forem. Isso nos dá legitimidade democrática puramente procedimental e a distingue da justiça, mesmo aceitando que a justiça não está concretada procedimentalmente. A legitimidade permite um certo grau de injustiça que a justiça não permite ${ }^{96}$.

Com essa citação, poderíamos retornar às objeções de Habermas ao liberalismo político de Rawls: a ideia de justiça substantiva volta a colocar vários dilemas fundamentais, como um critério de veracidade extra normativo dentro do próprio projeto de justiça como equidade. Nesse ponto, com efeito, o debate resta aberto.

\section{A proposta política de Habermas}

Nas obras indicadas pela referência bibliográfica, Habermas oferecenos uma visão geral da gênese dos atuais Estados nacionais e as diferentes concepções jurídicas que fomentaram os direitos básicos da cidadania ocidental. O foco fundamental de nosso autor foi expor os modelos liberal e republicano, como os mais proeminentes na configuração política democrática contemporânea.

A partir do liberalismo e do republicanismo, podemos reconstruir certos modelos políticos e sociais que oferecem dificuldades ao ordenamento jurídico que, segundo Habermas - como vimos em Debate sobre el liberalismo político - exige um alicerce sólido o suficiente para sua justificativa teórico-prática.

Habermas foi muito duro ao fazer sua crítica a esses modelos democráticos, porque nos mostra como podemos localizar suas acusadas falhas, na medida em que expõem certos riscos intrínsecos à democracia. O liberalismo político tem sido teoricamente tratado como um projeto baseado na estrutura mercantil, que assenta suas bases na autonomia pri-

${ }^{96}$ Ibid., p. 137. 
vada - a liberdade dos modernos - donde se manifestam evidentes carências de fundamentação.

Para Habermas, a política deliberativa é uma espécie de terceira via, que assume e supera as conquistas e deficiências do liberalismo e do republicanismo, constituindo não apenas uma possibilidade das facticidades sociopolíticas inerentes às constituições democráticas, mas também e isso é muito importante - por estabelecer um espaço de validade cognitiva para fundamentar teoricamente a práxis política, moral e jurídica.

A concepção procedimentalista da democracia deliberativa recorre a uma situação muito semelhante ao consenso sobreposto de Rawls, que busca sua justificativa invocando razões de aceitabilidade geral na deliberação de um cidadão que goza de uma situação de liberdade e igualdade, no âmbito de uma democracia constitucional.

Os discursos pragmático, ético e moral estão normativamente entrelaçados numa pretensão institucionalizadora da própria deliberação democrática. Dito de outro modo, a teoria da ação comunicativa constitui o cume de um longo processo ocupado em discutir as diferentes teorias contemporâneas da racionalidade, que o conduziram da tentativa fracassada de fundamentar epistemologicamente a relação teórico-prática conhecimento e interesse - à noção de razão comunicativa na qual Habermas acredita poder salvar o que resta da razão prática.

O ponto de partida, numa sociedade constituída democraticamente, é "a formação democrática da opinião e da vontade comum que se evidencia ou se concretiza nas eleições gerais e nas resoluções parlamentares"97. Naturalmente, não se trata de inventar novas fórmulas representativas, mas de repensar como se estabelecem mecanismos já conhecidos e a que dimensão prática alcança o exercício da democracia.

Consequentemente, Habermas não parte ex novo. Toda sua construção crítica é colocada na base de uma tentativa de melhoria abrangente. Se o republicanismo estabeleceu condições dialógicas extraordinárias, baseadas na autocompreensão ética, a seu turno, o liberalismo assentavase numa instrumentalidade política de marcada eficiência, que procurava a equidade no compromisso de interesses ${ }^{98}$. Trata-se de articular institu-

${ }^{97}$ Habermas, Inclusión del otro, p. 240.

98 Idem. 
cionalmente ambas as possibilidades, num quadro deliberativo que garantisse a eficácia das estruturas políticas na liberdade participativa de todos os cidadãos.

O quadro comunicativo, portanto, passa a ter precedência no projeto político habermasiano. Segundo ele, "o terceiro modelo de democracia que gostaria de propor baseia-se precisamente nas condições comunicativas sob as quais o processo político tem a presunção de produzir resultados racionais, porque se realiza em todos em sua extensão e de forma deliberativa. ${ }^{99}$ "

Com efeito, nesta via alternativa habermasiana, busca-se a complementaridade das liberdades públicas e privadas em uma nova esfera, cujo único controle reside na encarnação institucional do princípio do discurso ${ }^{100}$, que constitui o princípio regulador encarregado de introduzir a dimensão moral nesses processos de constituição e formação de vontades. E a normatividade positiva restringe-se às possibilidades de coparticipação no discurso racional.

Desta maneira, a pretensão de Habermas consistirá em integrar, "num procedimento ideal de deliberação e de tomada de decisão"101, toda a herança democrática do liberalismo e republicanismo, os quais cimentam aquilo que comumente conhecemos como democracia ocidental.

Em relação a isso, é preciso dizer que Habermas afirma que "esse procedimento democrático gera uma conexão interna entre negociações, discursos de autocompreensão e discursos referentes à justiça, além de consolidar a presunção de que, em tais condições, resultados racionais ou equitativos são passíveis de alcance"102. Em outras palavras, a integração processual busca a coesão social a partir da práxis política, mas não para por aí.

Para além do tecnicamente político, o social e o moral destinam-se a coexistir numa certa harmonia baseada na pluralidade de sujeitos que vivem na nossa sociedade. É por isso que Habermas assinala que "a razão prática afasta-se da noção dos direitos universais do ser humano ou

\footnotetext{
99 Ibid., p. 239.

100 Ibid., p. 212.

101 Ibid., p. 240.

102 Idem.
} 
da eticidade concreta de uma determinada comunidade e ruma para aquelas regras de discurso e formas de argumentação que tiram seu conteúdo normativo da validade da ação orientada para a compreensão e, em última instância, a estrutura da comunicação linguística”.

Assim, postula-se desta forma, um certo formalismo democrático baseado na institucionalização do discurso, o que implica a exigência de que o conceito de política deliberativa só tome "uma referência empírica quando levamos em conta a pluralidade de formas de comunicação em que se configura uma vontade comum, a saber: não só pela autocompreensão ética, mas também por acordos de interesses e compromissos, pela escolha racional dos meios em relação a um fim, pelos fundamentos morais e pela verificação do juridicamente coerente"103.

Com isso, apresenta-se o fenômeno de restrição da moralidade única, porque a moralidade pública passa a ser determinada, exclusivamente, pelas condições e pressupostos da deliberação democrática, uma das bases da laicidade. Com essas restrições procedimentais, desenvolver-seiam processos de discussão pública independentemente de sua nature$\mathrm{za}^{104}$, e o próprio fato discursivo institui o fórum público que, inicialmente, é mantido pelo processo eleitoral e parlamentar e, posteriormente, é reconhecido como autenticamente exercido no campo do associacionismo, onde tomam assento os grupos religiosos que participam dos foros públicos independentes ${ }^{105}$.

Para Habermas, "os procedimentos comunicativos e os pressupostos da formação democrática da opinião e da vontade funcionam como as balizas mais importantes para a racionalização discursiva das decisões de um governo e de uma administração sujeita ao direito e à lei"'106.

Nesse entrelaçamento, poder e legitimação estão sujeitos ao meio termo, que é a racionalização, sempre entendida a partir da política discursiva do projeto deliberativo e que sempre exige e supera um momento de programação comunitária, fiscalizada por um "controle" a posteriori. A preeminência imediata da deliberação social subordina o sistema político da função decisória a um segundo plano.

\footnotetext{
103 Ibid., p. 239.

104 Habermas, La Filosofia Moral y Politica, p. 239.

105 Habermas, Inclusión del otro, p. 240.

106 Ibid., p. 116.
} 
Isso se dá desta forma, ainda que, no entanto, a opinião pública transformada em poder comunicativo não possa comandar a si mesma, mas apenas direcionar o uso do poder executivo para certos canais. $\mathrm{O}$ princípio procedimental estabelece certos requisitos práticos, segundo os quais a atividade política procede da compreensão social.

Mas esta última, simultaneamente, sobrepõe-se à sua restrição normativa e isso significa que, embora a concorrência deliberativa seja o princípio legitimador do poder, este, nos termos de sua práxis administrativa, não pode estar sujeito à arbitrariedade de sua fonte legitimadora. Desse modo, tanto a autonomia do privado como a do público, parecem estar articuladas no procedimentalismo formal da política deliberativa.

Segundo Habermas,

é isso que se pretende evitar com esse novo paradigma procedimental, agora voltado para a realização e o aprimoramento - aqui e sim no sentido de Aufhebung - do conflito clássico entre a liberdade dos antigos e a liberdade dos modernos. Permite conciliar a tradicional dissociação entre autonomia público-privada, entre direitos humanos e soberania popular. E a sugestão é que abandonemos esse debate sobre quais dessas dimensões devem predominar, que viciou a filosofia política nos últimos dois séculos, e as consideremos pelo que são: complementares, tão importantes e baseadas em uma origem comum (gleichursprünglich). O objetivo é, portanto, que ambos sejam restringidos simetricamente para que fiquem em uma situação de equilíbrio mútuo. Esta reinterpretação da autonomia, a partir da teoria do discurso, significa, portanto, que a substância dos direitos fundamentais está contida nas condições formais daquele tipo de constituição de vontades e opiniões em que a soberania do povo assume forma jurídica ${ }^{107}$.

Para Habermas, a política deliberativa alcançou uma grande conquista, porque, por meio de um debate público autônomo e relevante, grandes conceitos como, soberania e legitimidade, não têm mais suas raízes em categorias dogmaticamente fechadas. Ao contrário, o exercício da democracia parece ir além do quadro tecnicamente político para se tornar um modus vivendi, que eleva o democrático ao âmbito da vida cotidia-

107 Habermas, Filosofia, p. 214-215. 
na, mantendo a possibilidade de uma sobreposição constante entre direitos e liberdades individuais e coletivas entendidas como um continuum.

A sociedade deixa de ser uma parcela do político, como afirmam os grupos secularistas, para se tornar a esfera dos eventos discursivos e, com isso, do eminentemente humano. O conceito discursivo de democracia corresponde, ao contrário, "à imagem de uma sociedade descentralizada que, com o surgimento do espaço público, certamente se transmutou numa plataforma diferenciada de percepção, identificação e deliberação dos problemas da sociedade como um todo"108.

Se as categorias típicas da filosofia do sujeito são dispensadas, então "a soberania não precisa se concentrar no povo, nem precisa ser banida para o anonimato dos poderes constitucionais de forma concreta" ${ }^{109}$. A democracia não requer um foro específico e limitado para seu exercício, mas sim que a própria sociedade seja um quadro dialógico de pessoas que zelam por seus interesses comuns.

Desse modo, tanto a identidade pessoal concreta supera os riscos do subjetivismo da filosofia idealista, que priva as pessoas de todo sentido, como categoria onde ocorrem direitos e liberdades, como do mero positivismo jurídico, que não se torna dono das possibilidades de autonomia. A estruturação social já implica relações interpessoais, num quadro de ação comunicativa abrangente e inclusiva.

A soberania popular surge das interações entre a formação da vontade comum, institucionalizada com técnicas próprias do Estado de Direito e os espaços públicos culturalmente mobilizados, que, por sua vez, encontram base nas associações de uma sociedade civil igualmente distante do mundo político quanto do econômico.

$\mathrm{O}$ associacionismo civil torna-se um projeto habermasiano, o vértice do bem fazer democrático na política deliberativa. A insistência em estabelecer essas possibilidades tanto fora do Estado quanto da economia aponta para a desconfiança das fontes factuais de poder incorporadas em ambas as instituições.

Em suma, a proposta procedimental de Habermas fala-nos de estabelecer uma rede de relações onde deveres e direitos são legitimados pelo

108 Habermas, Inclusión del otro, p. 245.

109 Idem. 
próprio procedimento discursivo, como um ambiente dinâmico onde a convivência se torna viável. Nesse sentido, a interpretação da democracia realizada em termos de teoria discursiva, vincula-se a uma consideração científico-social distante, segundo a qual o sistema político não é o centro nem o topo, nem mesmo o modelo de sociedade que cunhou suas estruturas, mas apenas um sistema de ação entre outros.

\section{Habermas e Ratzinger: dialética da secularização}

Em janeiro de 2004, um acontecimento extraordinário ocorreu do ponto de vista intelectual. Convidados pela Academia Católica da Baviera, dois grandes intelectuais europeus teriam uma conversa sobre os fundamentos morais do estado. Ambos os pensadores gozam de reconhecido prestígio em seus respectivos campos e fora deles: do ponto de vista secular, o prolífico filósofo Jürgen Habermas e, do ponto de vista religioso, o teólogo Joseph Ratzinger, então prefeito da Congregação para a Doutrina da Fé e que, meses depois, seria eleito como Papa Bento XVI.

Como consequência desse encontro, eles apresentariam dois trabalhos que foram compilados sob o título Entre a razão e a religião, dialética da secularização, cuja análise é obrigatória como pináculo desse ensaio.

Da parte de Habermas, ele começa referindo-se justamente ao que foi objeto de sua disputa com Rawls: a suposta neutralidade da cosmovisão de Rawls poderia fazer o Estado cambalear. Para superar a discussão anterior, ele deriva seu discurso em cinco seções, nas quais desenvolve as possibilidades políticas dos estados constitucionais a partir de princípios correlativos às seções anteriores.

Habermas posiciona-se, como Rawls, a partir de um liberalismo político entendido como republicanismo kantiano, que estabeleceria uma base normativa pós-metafísica e, portanto, não religiosa do Estado democrático. Estaríamos diante de um direito racional que teria renunciado à tradição da lei natural e suas consequentes implicações religiosas.

Com isso, ele, mais uma vez, reconhece que o ponto de partida histórico é o Iluminismo ${ }^{110}$. Com base nos estudos de Böckenförde, que

110 Joseph Ratzinger e Jürgen Habermas, Entre razón y religion. Dialéctica de la secularización (México: Fondo de Cultura Económica, 2008), p. 11-12. 
questionou se a ordem constitucional positivada exigia um suporte ético de natureza pré-política - como a moral religiosa que servisse como fundamento legitimador da legalidade -, Habermas afirma que "a concepção procedimental, inspirada em Kant, insiste numa justificativa autônoma de princípios constitucionais, com a pretensão de ser racionalmente aceitável para todos os cidadãos"111.

Portanto, o Estado não requer instâncias externas para apoiá-lo, seja de natureza ideológica ou religiosa, o que estabelece o princípio garantidor da neutralidade cosmovisional do Estado. A coesão social, que deve surgir da práxis política de um estado constitucional liberal, não pode ter sua origem no processo normativo, pois este atua sobre os cidadãos com caráter coercitivo, não podendo, portanto, a solidariedade cidadã ser imposta por lei.

Mas a aspiração habermasiana de que a participação cidadã se torne socialmente efetiva como modus vivendi, implica a aspiração ao que ele chama de "virtudes políticas", essenciais no processo de socialização, o que nos levaria a poder dizer que, "de certa forma, o status de cidadão está inserido numa sociedade civil que se alimenta de fontes espontâneas ou, se preferir, de fontes pré-políticas" ${ }^{112}$.

Habermas reincide na capacitação procedimental dos Estados democráticos para se munir autonomamente de todos os recursos necessários para promover a participação cidadã, se bem que reconhece que "a conformação de uma opinião e de uma vontade alimenta-se, em grande parte, de ideais éticos e aspectos culturais da vida do mundo" 113 , incluindo a compreensão religiosa e moralidade, que, por outro lado, historicamente, "prestaram um serviço de grande utilidade para a coesão social"114.

A proposta de Habermas para as democracias liberais gira em torno do polêmico conceito de patriotismo constitucional e que ele mesmo define como a situação em que "os cidadãos fazem seus os princípios da constituição, não apenas em seu conteúdo abstrato, mas sobretudo em

\footnotetext{
111 Idem.

112 Ibid., p. 17.

113 Idem.

114 Ibid., p. 18.
} 
seu sentido concreto no conteúdo histórico da respectiva história nacional" 115 e, com isso, ele assume a necessidade de reconhecer e praticar os processos de inculturação democrática, nos limites das propostas constitucionais, que devemos assumir a priori como neutras, do ponto de vista político, embora não tanto do ponto de vista moral.

Mas é preciso reconhecer que a realidade política, nacional e internacional, está sofrendo cada vez mais desgaste, devido ao crescente número de conflitos que resultam na fragmentação social da cidadania. Vale ressaltar que o processo de racionalização social não deu os resultados que dele se poderia esperar e, por isso, "o teorema de que uma modernidade desgastada só pode ajudá-la a sair do atoleiro em que se encontra por intermédio de uma orientação religiosa em direção a um ponto de referência transcendental"'116.

A filosofia, por sua vez, sempre que se aprofundou na reflexão sobre a origem da racionalidade humana, derivou no reconhecimento da alteridade em chaves do absoluto e, por isso, a filosofia deve estar aberta ao diálogo com as tradições religiosas. Nessa perspectiva, a secularização é, para Habermas, uma oportunidade de aprendizagem para a convivência social entre a mentalidade laica e a mentalidade religiosa que deve encontrar, no espaço público, um ambiente de mútuo enriquecimento dialógico.

A própria história do Cristianismo e do Ocidente dá um bom exemplo disso quando o Cristianismo assume a metafísica grega e, uma grande parte dos valores do Ocidente, também do ponto de vista normativo, vêm da cultura cristã. Se "ambas as posições, a religiosa e a secular, concebem a secularização da sociedade como um processo de aprendizagem complementar, então elas podem levar a sério suas contribuições em questões públicas polêmicas também do ponto de vista cognitivo"117.

A título de síntese sobre como as relações entre a cidadania religiosa e a não-religiosa devem ser, Habermas aponta, com agudeza, que as religiões monoteístas renunciaram, em grande medida, ao critério de verdade que as avaliava, a verdade revelada, fazendo incutir em seus membros esta inculturação, anteriormente aludida, pela qual cada sujeito divide sua

\footnotetext{
115 Ibid., p. 19.

116 Ibid., p. 22.

117 Ibid., p. 29.
} 
categoria de cidadão daquela de crente. O papel de membro de uma comunidade religiosa está assim separado do papel de cidadão, o que nos traz de volta a John Rawls e seu "módulo de justiça universal".

Isso conduz o Estado à aceitação do diálogo com as confissões religiosas, garantindo-lhes, assim, parte do diálogo social, como partes que são da sociedade civil. Ora, nenhuma distribuição deste tipo é simétrica e aí reaparece o drama da democracia.

Segundo Habermas, "é verdade que as consequências dessa tolerância não se distribuem simetricamente entre crentes e não-crentes, como fica evidente na legislação mais ou menos liberal sobre o aborto, mas também deve ser reconhecido que a consciência laica paga um preço por desfrutar da liberdade negativa que a liberdade de culto representa"118.

Ratzinger, por sua vez, posiciona seu discurso a partir da análise de dois fatores sintomáticos, que são o fenômeno da globalização e a possibilidade de produzir e destruir, o que o leva a questionar a necessidade de limitar o poder. Como terceiro fator, e não menos importante, está a possibilidade de que as culturas, que estão entrando em contato e transformando a fisionomia social do Ocidente, encontrem bases éticas para construir sobre elas uma estrutura jurídica eficaz que controle e ordene o poder.

A situação parece delicada quando "no processo de encontro e de interpenetração das culturas explodiram as certezas éticas sustentadas até agora" 119 , pois a imagem do homem não pode ser alterada por descobertas científicas, que parecem ter desempenhado um papel essencial na demolição de velhas certezas morais. Ratzinger exige que a ciência e a filosofia atuem com responsabilidade suficiente para não alterar, gratuitamente, a concepção integral do homem.

Do nível político, ele afirma que o poder deve estar sujeito ao direito, o qual deve ser colocado acima de qualquer suspeita ou de tentação da arbitrariedade. Isso leva ao questionamento da origem do direito para que atenda a critérios de justiça e não ao privilégio de quem detém o poder. Nesse sentido, o direito a que alude Ratzinger deve ser uma expressão do interesse comum de todos.

118 Ibid., p.31.

119 Ibid., p. 36. 
A resolução inicial do problema estaria na participação democrática consensuada, uma vez que a imbricação entre poder e direito derivaria do plano participativo do jogo eleitoral. No entanto, a formação democrática de consensos não tem, como instrumentos indispensáveis, outra coisa que a delegação de um lado e, de outro, a decisão da maioria.

Isso não impede que as maiorias sejam "cegas ou injustas e gerem leis iníquas, o que nos convida a refletir sobre os fundamentos democráticos do direito que deve atender, segundo a proposta de Ratzinger, a alguns princípios pré-políticos, cujo exemplo dos direitos humanos, hoje, apresentam-se como princípios inquestionáveis da civilização ocidental.

Novas ameaças pairam sobre a humanidade e representam um sério desafio reflexivo e normativo. Ameaças que envolvem abusos de poder, não necessariamente políticos. Outras escudadas nas possibilidades de desenvolvimento científico e tecnológico. O terrorismo está presente em qualquer momento nos países ocidentais e, às vezes, recebe uma certa legitimidade moral. Às vezes, ele se esconde por detrás do fanatismo religioso, o que levanta sérias dúvidas sobre a necessidade de colocar as religiões sob tutela.

Por outro lado, o desenvolvimento científico permite a manipulação e o controle biológico do homem, o que significa que o homem é capaz de criar o homem transformando-o em produto. Agora, finalmente, a reificação estrita e integral do humano tornou-se efetiva. Tudo isso leva Ratzinger a questionar a própria razão, que parece não ter limites: "A razão não deveria ser posta em observação? Mas, por meio de quem ou o quê?"120.

Numa seção dedicada ao direito natural, Ratzinger cobre brevemente cinco momentos do direito natural na história:

a. Grécia, onde surge da perda da validade das religiões tradicionais como fundamento natural da essência humana, o que significa que o direito saiu do campo da arbitrariedade e da contingência para passar a um fundamento normativo universalizável à espécie humana;

b. Após a descoberta da América, tem-se a experiência de que a lei cristã não é o único conteúdo normativo possível. A experiência de ou-

120 Ibid., p. 42-44. 
tras culturas levou Francisco de Vitória a desenvolver o ius gentium ou direitos dos povos, anteriores à concepção cristã do direito;

c. Um forte momento de lei natural veio com a divisão do Cristianismo pela Reforma Protestante. Os fundamentos normativos do ethos ocidental são anteriores ao dogma religioso, que garante a unidade moral do mundo cristão, mesmo que seja dividido em diferentes confissões. A identidade europeia era garantida pelo direito. Segundo Ratzinger, "o direito natural continuou a ser - especialmente na Igreja Católica - o argumento com o qual se apela à razão comum no diálogo com a sociedade laica e com outras comunidades religiosas e se buscam as bases para a compreensão dos princípios éticos de direito em uma sociedade laica e pluralista. Mas esse instrumento, infelizmente, não é mais fiável"121;

d. Assumindo que razão e natureza estavam interligadas, a lei natural sustentava uma ordem racional do universo e, consequentemente, também do humano que o evolucionismo rompeu;

e. Como último elemento reminiscente do direito natural, poderíamos apontar os direitos humanos, que justamente por suas características anteriores à ordem política e porque diz respeito a todo homem, são entendidos como universais e inalienáveis. Eles não são inventados, mas são descobertos. Neles, Ratzinger vê a última fortaleza não positivista.

Sobre a universalidade dos direitos humanos e suas possibilidades, deter-nos-íamos na reflexão obrigatória sobre a interculturalidade. Nesse campo, deve-se dizer que tanto o cristianismo quanto o racionalismo ocidental reivindicam a universalidade de sua cosmovisão, mas atinge os limites da inaceitabilidade por outras culturas entre outras razões porque, dentro das diferentes áreas, já não existe uniformidade.

Por outro lado, a cultura secular racional é realmente preponderante e se concebe como elemento unificador dos novos modelos sociais, mas "a verdade é que a compreensão cristã da realidade continua a ser uma força ativa" 122 . Em todo caso, Ratzinger aponta a falta de universalidade factual das duas grandes culturas do Ocidente.

121 Ibid., p. 46.

122 Ibid., p. 50. 
Para concluir o seu discurso, reconhece que, tanto nas religiões como nas esferas de racionalidade, existem patologias que devem ser corrigidas, para que "na necessária correlação entre ciência e fé, razão e religião, chamadas a purificar-se e a regenerar-se reciprocamente, percebam que precisam uma da outra"123.

Ao longo deste caminho, Ratzinger vislumbra o futuro da Europa e do mundo. O desafio não é fácil, mas não há uma verdadeira sociedade civil sem instituições sólidas, vitais e verdadeiras, nas quais os aportes teóricos, provenientes de alguns princípios pré-políticos e mesmo das confissões religiosas, desde que lastreados em argumentos de razões públicas, podem e devem ser ouvidos na arena pública do debate filosófico-político, a fim de se fomentar uma fecunda laicidade, porquanto tais princípios e confissões são também capazes de detectar injustiças, sugerir respostas para os problemas de convivência e, sobretudo, afiançar os laços de solidariedade entre os indivíduos, na medida em que são fontes de interpretação da realidade capazes de oferecer contribuições articuladas que veem o homem mais além de um contexto estritamente mundano.

123 Idem. 


\section{Referências citadas}

HABERMAS, Jürgen. Facticidady validez: Madrid: Trotta, 1998.

_.. La filosofia moral y política. Madrid: Biblioteca Nueva, 1997.

_. La inclusión del otro. Barcelona: Paidós, 1999. . Pensamiento post-metafísico. Madrid: Taurus, 2000.

RATZINGER, Joseph; HABERMAS, Jürgen. Entre razón y religion. Dialéctica de la secularización. México: Fondo de Cultura Económica, 2008.

RAWLS, John. El liberalismo político. Barcelona: Herder, 1996.

. Uma Teoria da Justiça. 3. ed. São Paulo: Martins Fontes, 2008.

RAWLS, John; HABERMAS, Jürgen. Debate sobre el liberalismo politico. Barcelona: Paidós, 1998. 


\title{
Laicité in the Current Philosophical-Political Debate
}

\begin{abstract}
: in a liberal political environment where a certain political constructivism (Rawls) is actively fostered, churches can participate in the public sphere, because religious culture can illuminate certain vital aspects that, in an epistemologically scientific, rationally instrumental, and financially economicist context, have remained forgotten, insofar as religions do not cease to shape the cultural models of the great civilizations (Habermas).
\end{abstract}

KEYwORDS: Rule of law; Religion; Rawls; Habermas; Ratzinger. 